\title{
Analisis Pengaruh Kompetensi Bawahan Dan Gaya Kepemimpinan Terhadap Efektivitas Organisasi
}

\author{
Lesnussa Johny ${ }^{1}$
}

STIA Trinitas Ambon (081343005518)

\begin{abstract}
This research analyzed some problems, such as: influence of the subordinate competence (X1) and leadership style (X2) toward effectiveness of the organization (Y). Hypothesis of this research is, first, it is presumed that both subordinate competence and leadership style have simultaneously significant influence toward effectiveness of the organization. Second, it is presumed that leadership style has dominant influence toward effectiveness of the organization. Data analysis technique uses multiple regressions. Technique of the sample collecting uses census. Result of the multiple linear regression analysis shows that variables of subordinate competence and leadership style have significant influence toward effectiveness of the organization, therefore, the first hypothesis is accepted. The test result of the regression coefficient value resulted by each independent variable shows that independent variable of leadership style $(0.427)$ has the highest value for the regression coefficient in comparison with the independent variable for the subordinate competence (0.288). The comparison result of the regression coefficient values resulted by each independent variable shows that the second hypothesis is accepted.
\end{abstract}

Keywords : Subordinate competence, leadership style, effectiveness of the organization

\section{PENDAHULUAN}

Dalam melaksanakan pembangunan, Pemerintah Daerah merupakan sub sistem dari Pemerintah Pusat dan hakekat pembangunan menuntut kemandirian daerah yang semakin lama semakin besar. Langkah awal proses reformasi penyelenggaraan pemerintahan daerah adalah dengan diundangkannya: Undang -undang Nomor 22 Tahun 1999 tentang Pemerintahan Daerah dan Undang - undang Nomor 25 Tahun 1999 tentang Perimbangan Keuangan antara Pemerintah Pusat dan Pemerintah Daerah, yang pada gilirannya diharapkan mampu meningkatkan kesejahteraan seluruh rakyat. Hal ini dimaksudkan sebagai usaha awal untuk mengubah pendekatan pembangunan dari sistem top down menjadi bottom up sesuai jiwa dan semangat Undang - Undang Dasar 1945, dalam rangka memberi kesempatan bagi peningkatan demokrasi dan kinerja daerah yang efektifdan efisien. Dengan demikian aparatur negara harus mampu menjawab tantangan ketinggalan daerah antara lain dengan: membangun kapasitas institusi pemerintah daerah yang berkualitas, melalui peningkatan pelayanan kepada masyarakat. Karena stigma negatif yang berkembang saat ini, bahwa: berhubungan dengan birokrasi berarti berhadapan dengan berbagai prosedur yang berbelit-belit, tidak transparan, memakan waktu lama dan mungkin juga menyebalkan karena sikapnya yang angkuh dan cuek. Ini berarti derasnya tuntutan otonomi daerah merupakan harapan untuk memajukan pemerintah daerah, namun disisi lain eksistensi daerah dengan

\footnotetext{
${ }^{1}$ Lesnussa Johny adalah Dosen STIA Trinitas Ambon.
} 
sumber daya yang dimiliki terutama kualitas Sumber Daya Manusia yang tidak merata merupakan kendala yang perlu segera diatasi.

Setiap organisasi pasti menginginkan kelangsungan hidupnya, dalam arti dapat mengatasi hambatan yang dapat mengganggu stabilitas organisasi. Atau dengan kata lain setiap organisasi menghendaki pencapaian tujuan yang efektif. Untuk mengukur seberapa jauh efektivitas organisasi sangatlah mengalami kesukaran, hal ini dikarenakan keefektifan organisasi memiliki defenisi yang relatif. Campbell dalam Robbins (1994: 55), mengidentifikasikan kriteria berbeda yang dipakai untuk mengukur efektivitas organisasi, mulai dari keefektifan keseluruhan sampai dengan penekanan pada performa. Namun kriteria tersebut semuanya tidak relevan bagi suatu organisasi, dan dapat dipastikan beberapa diantaranya lebih penting dibandingkan yang lain. Fungsi organisasi yang berbeda-beda harus dievaluasi dengan menggunakan karakteristik yang berbeda pula.

Kompetensi Bawahan mencakup kualitas seorang pegawai yang dibutuhkan untuk menjalankan pekerjaan, sedangkan gaya kepemimpinan merupakan dukungan manajerial, baik dengan membangun sistem kerja dan hubungan yang aman dan harmonis, maupun dengan mengembangkan kompetensi pegawai pada organisasi.

Obyek penelitian ini adalah Dinas Pendapatan Daerah Kota Ambon sebagai salah satu komponen dalam jajaran Pemerintah Daerah, memiliki peran strategis. Manajemen Pegawai Negeri Sipil Daerah adalah: keseluruhan kegiatan dan upaya untuk meningkatkan efisiensi, efektivitas, dan derajat profesionalisme penyelenggaraan tugas, fungsi, dan kewajiban kepegawaian.

Latar belakang pendidikan pegawai bervariasi dari mulai pendidikan formal SD sampai pendidikan formal Magister (S2). Latar belakang pendidikan dapat menjadi salah satu parameter untuk menunjukkan kualitas sumber daya manusia. Dari aspek kualitas Sumber Daya Manusia hal ini masih memadai dibandingkan dengan beban tugas yang harus dilaksanakan, karena: terdapat kecenderungan bahwa alokasi aparatur berkualitas selama ini ada pada tingkat pemerintah pusat atau propinsi. Padahal ujung tombak pelaksanaan otonomi daerah ada pada tingkat daerah Kota/kota, sehingga perlu dilakukan pengembangan pegawai demi tersedianya SDM yang memadai sesuai bidang tugas yang diemban oleh PNS yang bersangkutan.

Bila ada kesempatan seorang pegawai diangkat dalam jabatan struktural berarti pegawai tersebut diberi kesempatan dan kepercayaan untuk menumbuhkan dan mengembangkan kemampuan yang dimilikinya, sehingga bila tidak adanya dukungan kompetensi SDM yang memadai, maka mungkin saja pegawai tersebut menduduki jabatan struktural dalam organisasi, tetapi tidak menjadi pemimpin yang efektif, karena kompetensi merupakan faktor mendasar yang dimiliki seseorang, sehingga mempunyai kemampuan lebih dan membuatnya berbeda dengan orang lain dalam pencapaian tujuan.

Keberhasilan suatu organisasi baik secara keseluruhan maupun berbagai kelompok, sangat tergantung pada kompetensi karyawan/pegawai dan penerapan mutu kepemimpinan untuk mengelola sumber daya organisasi dalam menyelenggarakan berbagai kegiatannya. Diharapkan dengan penerapan gaya kepemimpinan yang baik dan optimalisasi sumber daya aparatur dapat mengefektifkan organisasi, demi terciptanya kepemerintahan yang baik (good governance),

Tujuan penelitian ini untuk: menganalisis pengaruh kompetensi bawahan dan gaya kepemimpinan terhadap efektivitas organisasi, serta menganalisis pengaruh Variabel yang paling dominan diantara kompetensi bawahan dan gaya kepemimpinan terhadap efektivitas organisasi. 
Pada hakekatnya organisasi adalah wadah tempat berlangsung interaksi antar anggota organisasi. Efektivitas setiap organisasi sangat dipengaruhi oleh perilaku manusia yang merupakan sumber daya umum bagi organisasi. Semakin berprestasi seseorang, kelompok ataupun organisasi, semakin menunjukkan efektivitasnya.

Victor A. Thomson dalam Thoha (1984: 125-126) menyatakan bahwa: suatu organisasi adalah suatu integrasi dari sejumlah spesialis-spesialis yang bekerja sama sangat rasional dan impersonal untuk mencapai beberapa tujuan spesifik yang telah ditetapkan sebelumnya". Menurut Chester Bernard: "suatu organisasi adalah suatu sistem dari aktivitas - aktivitas yang terkoordinasikan secara sadar atau kekuatankekuatan yang terdiri dari dua orang atau lebih".

Umumnya defenisi organisasi menekankan aspek tujuan atau aspek sasaran demi pencapaian efektivitas organisasi yang merupakan tanggung jawab pada tingkat managerial/pemimpin. Sebagaimana dikemukakan Chester Bernard dalam Thoha (1984:128), menjelaskan karakteristik organisasi antara lain organisasi terdiri dari serangkaian kegiatan yang dicapai lewat suatu proses kesadaran, kesengajaan dan koordinasi yang bersasaran; organisasi merupakan kumpulan orang-orang untuk melaksanakan kegiatan yang bersasaran jelas tersebut. Organisasi memerlukan adanya proses komunikasi, yakni: suatu hasrat dari sebagian anggotanya untuk mengambil bagian dalam pencapaian tujuan bersama dengan anggota lainnya.

Richard N. Steers dalam Nawawi (2003: 40), mengatakan bahwa efektifitas dinilai dari seberapa jauh organisasi berhasil mencapai tujuan yang seharusnya dicapai. Menurut Stoner dan Wankel (1996, p.391), yang menyatakan efektivitas (effectiveness) atau keefektifan hakikatnya merujuk pada kemampuan untuk mencapai tujuan secara memadai dengan melaksanakan pekerjaan secara benar. Pencapaian tujuan organisasi dilakukan secara bertahap, dimana tingkat yang paling rendah pada mulanya bersumber dari efektivitas individu dalam organisasi, kemudian berkembang menjadi efektivitas kelompok. Melalui proses interaksi tersebut, pada akhimya organisasi mampu menghasilkan efektivitas yang lebih tinggi.

Dari uraian tersebut, tampak bahwa kualitas SDM atau kompetensi pegawai secara individu maupun kelompok sangat diandalkan dalam upaya pencapaian efektivitas organisasi. Karena dalam setiap organisasi selalu terdapat (2) dua kelompok manusia, yakni: kelompok pimpinan dan kelompok staf. Kelompok pimpinan: berpengetahuan generalis dan berketrampilan manajerial (manajerial skill), menangani fungsi-fungsi strategik organisasi; sedangkan Kelompok staf atau bawahan: berpengetahuan spesialis dan berketrampilan teknis (tehnical skill), melaksanakan kegiatan operasional organisasi; maka efektivivtas organisasi berkaitan dengan prestasi pimpinan (penerapan gaya kepemimpinan) maupun prestasi bawahan (kompetensi yang dimiliki).

Menurut Gibson (1996; 38-57), terdapat 3 (tiga) pendekatan untuk mencapai efekti vitas organisasi, pertama, pendekatan optimalisasi tujuan, perspektif efektivitas yang menekankan peran sentral dari pencapaian tujuan sebagai kriteria untuk menilai efektivitas. Setiap organisasi mengejar tujuan yang berbeda sehingga evaluasi yang efektif harus dapat melihat keunikan tujuan yang ingin dicapai oleh masing-masing organisasi tersebut. Tujuan organisasi dianggap sebagai kondisi akhir yang statis.

Kedua, pendekatan sistem dalam organisasi, pendekatan dalam menganalisis perilaku organisasi dengan penekanan pada mempertahankan elemen dasar masukanproses-keluaran dan mengadaptasi terhadap lingkungan yang lebih luas yang menopang organisasi. Pendekatan ini mengimplementasikan bahwa organisasi terdiri dari sub-sub bagian yang berhubungan dengan struktur dan urutan-urutan proses kegiatan dalam 
mencapai tujuan organisasi. Tujuan organisasi tidak dianggap sebagai kondisi akhir yang statis (seperti optimalisasi tujuan) melainkan suatu hal yang mungkin berubah atau dapat diubah selama rentang waktu tertentu. Tujuan organisasi dapat dipilah-pilah mengikuti suatu siklus waktu, sehingga dapat dipelajari tujuan jangka pendek maupun tujuan jangka panjang organisasi, dimana pencapaian tujuan jangka pendek memberi andil untuk mencapai tujuan jangka panjang organisasi yang bersangkutan.

Ketiga, pendekatan efektivitas model multiple constituency, pendekatan yang menekankan pentingya hubungan relatif diantara kepentingan kelompok dan individual dalam suatu organisasi. Pandangan ini hanya memenuhi tuntutan dari hal-hal dalam lingkungan yang dapat mengancam kelangsungan hidupnya. Oleh karena itu, keberhasilan adalah kemampuan untuk memuaskan konstituensi yang menjadi pendukung kelanjutan eksistensi organisasi (individu, kelompok serta lembaga yang menjadi tempat bergantung kelangsungan kegiatan).

Kompetensi merupakan keterampilan, pengetahuan dan sikap utama yang diperlukan untuk mencapai kinerja yang efektif dalam pekerjaan. Menurut Peraturan Pemerintah Nomor 100 Tahun 2000, kompetensi adalah kemampuan dan karakteristik yang dimiliki oleh seorang PNS berupa pengetahuan, keterampilan dan sikap perilaku yang diperlukan dalam pelaksanaan tugas.

Kompetensi adalah: kemampuan dan ketrampilan melakukan kerja. Kompetensi setiap orang, dipengaruhi oleh faktor kemampuan dan ketrampilan kerja serta faktor motivasi dan etos kerja (Simanjuntak 2005:10). Kemampuan dan ketrampilan kerja dipengaruhi oleh kebugaran fisik dan kesehatan jiwa individu yang bersangkutan, pendidikan, akumulasi pelatihan dan pengalaman kerjanya. Kebugaran fisik membuat orang mampu dan tahan bekerja. Gangguan kejiwaan akibat frustasi dan masalah sosial ekonomi, membuat pekerja tidak konsisten dan tidak berkonsentrasi. Kemampuan bisa bersifat pembawaan sejak lahir atau diperoleh dari proses belajar melalui pendidikan, pelatihan dan pengalaman.

Pendidikan dan pelatihan diperlukan sebagai fungsi pengembangan dan merupakan bagian dari investasi sumber daya manusia (human investment). Menurut Notoatmojo (1998:25) Pendidikan dalam suatu organisasi adalah proses pengembangan kemampuan kearah yang diinginkan oleh organisasi yang bersangkutan, sedangkan Pelatihan merupakan bagian dari suatu proses pendidikan, yang tujuannya untuk meningkatkan kemampuan atau keterampilan khusus seseorang atau kelompok. Pendidikan berperan dalam pengembangan kemampuan untuk dapat menyesuaikan diri dengan lingkungannya, sedangkan Pelatihan ditujukan untuk meningkatkan keterampilan kerja agar lebih mudah melaksanakan tugasnya. Semakin tinggi waktu yang digunakan seseorang untuk pendidikan dan pelatihan, semakin tinggi kemampuannya melakukan pekerjaan.

Pengalaman kerja dapat memperdalam dan memperluas kemampuan kerja. Semakin sering seseorang melakukan pekerjaan yang sama, semakin terampil dan semakin cepat dia menyelesaikan pekerjaan tersebut. Semakin banyak macam pekerjaan yang dilakukan, pengalaman kerjanya semakin kaya dan luas. Motivasi dan etos kerja sangat penting mendorong semangat kerja. Motivasi dan etos kerja dipengaruhi oleh latar belakang keluarga, lingkungan masyarakat, budaya dan nilai-nilai agama yang dianutnya. Seseorang yang melihat pekerjaan sebagai beban dan keterpaksaan untuk memperoleh uang, akan mempunyai kinerja yang rendah, sebaliknya seseorang yang memandang pekerjaan sebagai kebutuhan, pengabdian, tantangan dan prestasi, akan menghasilkan kinerja yang tinggi demi pencapaian efektivitas organisasi.

Konsep human capital memposisikan karyawan sebagai input seperti halnya 
faktor produksi mesin dan peralatan, tetapi MSDM memandang karyawan dalam organisasi tidak hanya sebagai obyek yang menghasilkan output tetapi juga sebagai subyek yang perlu menikmati output. dengan organisasi karena alasan tertentu seperti berakhirnya kontrak kerja, pensiun, pemecatan atau pemberhentian atas karyawan tersebut.

Menurut Covey, Roger dan Rebecca Merill (1994) dalam Sedarmayanti (2003:150), kompetensi menimbulkan implikasi strategis yang sangat positifbagi kegiatan perencanaan dan pengelolaan sumber daya aparatur pemerintah dilingkup apapun dalam setiap kegiatan. Kompetensi tersebut mencakup antara lain, kompetensi teknis: pengetahuan dan keahlian untuk mencapai hasil yang telah disepakati, kemampuan untuk memikirkan persoalan dan mencari altematif-alternatif baru. Kompetensi konseptual: kemampuan untuk melihat gambar besar, untuk menguji berbagai pengendalian dan pengubah perspektif. Kompetensi untuk hidup: dalam saling ketergantungan kemampuan secara efektif dengan orang lain, termasuk kemampuan untuk mendengar, berkomunikasi, mendapat altematif lain, menciptakan kesepakatam, menang-menang dan berusaha mencapai solusi altematif lain, kemampuan untuk melihat dan beroperasi secara efektif dalam organisasi atau sistem yang utuh. (Mangkunegara 2006:112).

Tingkat kompetensi mempunyai implikasi praktis dan memberi gambaran bahwa kompetensi (Knowledge Competencies) dan Keahlian (Skill Competencies) cenderung lebih nyata dan relatif sebagai salah satu karakteristik yang dimiliki manusia, sedangkan selft-concept, trait dan motives berada pada titik sentral kepribadian seseorang (Spencer and Spencer, 1993). Implementasi kompetensi bawahan, didasarkan pada pengertian dan pemahaman untuk memberikan gambaran tentang kekuatan dan kelemahan dari individu PNS, sehingga kajian kompetensi bawahan dalam penelitian ini dianalisis dari faktor kemampuan dan ketrampilan kerja yang terdiri dari; kemampuan, kebugaran fisik dan kesehatanjiwa, pendidikan, pelatihan, pengalaman kerja.

Dalam sistem birokrasi pemerintah, pemimpin merupakan kedudukan panutan (informal) yang diakui, diterima dan didukung oleh para pengikutnya. Menurut Robbins (1991:354) dalam Nawawi (2003:20): "Kepemimpinan adalah kemampuan mempengaruhi suatu kelompok kearah pencapaian tujuan". Pendapat ini memandang semua anggota organisasi sebagai satu kesatuan dan dapat dipengaruhi untuk bersedia melakukan kegiatan dalam mencapai tujuan.

Kepemimpinan adalah upaya menggunakan berbagai jenis pengaruh yang bukan paksaan untuk memotivasi anggota organisasi agar mencapai tujuan tertentu. Motivasi tersebut, merupakan dorongan yang datang dari dalam diri berupa kesadaran dan bukan bersifat intimidasi melalui ancaman/hukuman. (Gibson,dkk 1997:334)

Kajian kepemimpinan dalam penelitian ini, dianalisis dengan menggunakan pendekatan perilaku (behavior) yakni: inisiasi struktur (initiating structure) dan pertimbangan / konsiderasi (consideration). Karena kedua gaya kepemimpinan tersebut saling sinergik (tidak saling mempengaruhi dan tidak memiliki ketergantungan) terhadap efektivitas kepemimpinan, dimana pemimpin yang efektifadalah yang bergaya inisiasi struktur tinggi dan bergaya konsiderasi tinggi.

Gaya inisiasi struktur ditandai oleh gaya pemimpin yang aktif membuat berbagai rencana, pengorganisasian, pengendalian dan koordinasi segala aktivitas yang dilakukan bawahan. Pemimpin dengan gaya ini, ditandai dengan perilaku: Mengutamakan tercapainya tujuan; Penetapan standar perilaku kerja; Pengaturan aktivitas kerja bawahan; Pemberian informasi tentang syarat pekerjaan tertentu; Penggunaan prosedur - prosedur kerja yang umum serta ketegasan pelaksanaan disiplin; 
Gaya konsiderasi yaitu: gaya kepemimpinan yang cenderung senang membuat berbagai pertimbangan dalam berbagai tindakannya, memprioritaskan perhatiannya pada kesejahteraan bawahan, memandang penting status dan keselarasan. Asumsinya: bawahan akan bekerja dengan baik jika pemimpin mampu membuat pekerjaan lebih mudah untuk diselesaikan, menaruh rasa hormat, tidak menonjolkan posisi formalnya dan tidak menyukai kekerasan. Pemimpin dengan gaya ini, ditandai dengan perilaku: Kesediaan pemimpin dalam menerima pendapat bawahan; Senang membantu bawahan memecahkan masalah.

Dalam Sedarmayanti (2003:127), kompetensi (Competence) sebagaimana diutarakan oleh pakar, antara lain konsep luas, membuat kemampuan mentransfer keahlian, kemampuan kepada situasi baru dalam wilayah kerja. Menyangkut organisasi dan pekerjaan, inovasi dan mengatasi aktivitas personel yang dibutuhkan ditempat berkaitan dengan rekan kerja, manajer serta pelanggan (Training Agency, 1988) b. Kemampuan dan kemauan untuk melakukan tugas (Burgoyne, 1988) c. Dimensi perilaku yang mempengaruhi kinerja (Woodruffe, 1990) d. Karakteristik individu apapun yang dapat dihitung dan diukur secara konsisten, dapat dibuktikan untuk membedakan secara signifikan antara kinerja yang efektif dengan yang tidak efektif (Spencer et al, 1990) e. Kemampuan dasar dan kualitas kinerja yang diperlukan untuk mengerjakan pekerjaan dengan baik (Fumham, 1990) f. Bakat, sifat dan keahlian individu apapun yang dapat dibuktikan, dapat dihubungkan dengan kinerja yang efektif dan baik sekali (Murphy, 1993), (Amstrong 1996; 189)

Selain itu kompetensi dinyatakan sebagai seperangkat tindakan cerdas penuh tanggung jawab yang dimiliki seseorang sebagai syarat untuk dianggap mampu oleh masyarakat dalam melaksanakan tugas-tugas dibidang pekerjaan tertentu (Mendiknas, 045/U/2002).

Dalam suatu organisasi, kompetensi merupakan faktor mendasar yang perlu dimiliki oleh seorang bawahan, sehingga seorang bawahan atau pegawai mempunyai kemampuan lebih dan membuatnya berbeda dengan seseorang yang mempunyai kemampuan rata-rata atau biasa saja. Dengan demikian kompetensi bawahan yang tersedia dalam organisasi, merupakan komponen penting demi terciptanya efektivitas suatu organisasi.

Pemimpin memiliki kewenangan dan memikul tanggung jawab mengelola kegiatan-kegiatan untuk mewujudkan tujuan organisasi, selalu memerlukan bantuan atau kerja sama anggota organisasi di lingkungannya. Efektivitas pencapaian tujuan organisasi sangat tergantung pada kualitas bantuan atau kerja sama yang diciptakan dan dikembangkan oleh pemimpin, baik yang dilakukan dengan cara perseorangan maupun kelompok didalam atau diluar unit yang terdapat didalam organisasi.

Menurut buku kepemimpinan yang efektif Nawawi (2003:26), mengatakan bahwa: kepemimpinan dapat diartikan sebagai kemampuan / kecerdasan mendbrong sejumlah orang (dua orang atau lebih) agar bekerja sama dalam melaksanakan kegiatan - kegiatan yang terarah pada tujuan bersama. Greenberg dan Bacon (2000,p.445) dalam Nawawi (2003:28) mengatakan bahwa: kepemimpinan adalah suatu proses dimana seorang pemimpin mempengaruhi anggotanya untuk mencapai tujuan kelompok atau organisasinya.

Pengertian lain diketengahkan oleh Blanchard dalam Wahjosumijo (1992:25) mengatakan, kepemimpinan adalah proses mempengaruhi kegiatan-kegiatan seseorang atau kelompok dalam usahanya mencapai tujuan organisasi. Sejalan dengan pendapat tersebut Sondang P. Siagian (1994:36) mengatakan bahawa: kepemimpinan merupakan inti manajemen yakni sebagai motor penggerak bagi sumber-sumber dan alat-alat dalam 
organisasi.

Pencapaian efektivitas dalam organisasi tergantung atas cara memimpin yang dipraktekkan pemimpin tersebut. Kepemimpinan dalam suatu organisasi akan sangat mempengaruhi gerak laju dari organisasi itu sendiri, hal tersebut terjadi karena pemimpin organisasi yang menentukan akan dibawa kemana organisasi itu bergerak (Suprihanto, 2003:93).

Model Hipotesis dalam penelitian ini antara lain kompetensi bawahan dan gaya kepemimpinan berpengaruh terhadap efektivitas organisasi, kedua, gaya kepemimpinan berpengaruh dominan terhadap efektivitas organisasi.

\section{METODE}

Rancangan Penelitian ini menggunakan pendekatan explanatif dengan teknik survey untuk menjelaskan hubungan kausalitas antara variabel kompetensi bawahan dan gaya kepemimpinan terhadap efektivitas organisasi serta hubungan antar indikator utama yang menjelaskan variabel-variabel tersebut.

Penelitian ini mencakup aspek pengembangan Sumber Daya Manusia khususnya kompetensi disamping pengkajian teori tentang gaya kepemimpinan dan efektivitas organisasi.

Kompetensi (XI) adalah: kemampuan dan ketrampilan melakukan kerja yang dipengaruhi oleh: kebugaran fisik dan kesehatan jiwa individu yang bersangkutan, pendidikan, akumulasi pelatihan dan pengalaman kerjanya (Simanjuntak 2005:10);

Kepemimpinan (X2) adalah: kemampuan mempengaruhi, menggerakkan dan mengarahkan pegawai agar bekerja sama melakukan kegiatan yang sesuai dengan keinginan pimpinan kearah pencapaian tujuan yang telah digariskan oleh organisasi (Siagian, 1979:67); Kajian ini, menggunakan 2(dua) gaya kepemimpinan, antara lain Gaya Inisisasi Struktur, gaya inisiasi struktur ditandai oleh gaya pemimpin yang aktif membuat berbagai rencana, pengorganisasian, pengendalian dan koordinasi segala aktivitas yang dilakukan bawahan;dan Gaya Konsiderasi Gaya konsiderasi yaitu: gaya kepemimpinan yang cenderung senang membuat berbagai pertimbangan dalam berbagai tindakannya, memprioritaskan perhatiannya pada kesejahteraan bawahan, memandang penting status dan keselarasan.

Efektivitas organisasi (Y) merupakan prestasi pimpinan dan bawahan dalam mencapai tujuan organisasi sesuai rencana yang ditetapkan. Apabila realisasi kegiatan semakin mendekati tujuan, maka semakin efektif organisasi tersebut, efektivitas hakikatnya merujuk kepada kemampuan untuk mencapai tujuan secara memadai dengan melaksanakan pekerjaan secara benar (Nawawi 2003:40).

Populasi dalam penelitian ini adalah: seluruh karyawan aparatur pemerintah daerah yang bekerja pada Dinas Pendapatan Daerah Kota Ambon, terdiri dari: 37 orang. Pengambilan sampel dilakukan dengan menggunakan metode sensus dimana semua anggota populasi dijadikan sampel.

Data yang telah terkumpul setelah uji validasi dan realibilitasnya akan dianalisa. Teknik analisa data yang digunakan dalam penelitian ini adalah regresi linear berganda dengan rumus :

$$
\mathrm{Y}=\mathrm{a}+\mathrm{b} 1 \mathrm{X} 1+\mathrm{b} 2 \mathrm{X} 2+\mathrm{e}
$$

dimana, $\mathrm{Y}=$ Efektivitas organisasi, $\mathrm{XI}=$ Kompetensi bawahan, $\mathrm{X} 2=$ Gaya

Kepemimpinan, $\mathrm{a}=$ Konstanta, $\mathrm{b}=$ Koefisien regresi, $\mathrm{e}=$ Residual $/$ variabel pengganggu

\section{HASIL}

Uji Hipotesis 1 (Uji F) Hipotesis pertama menyatakan diduga variabel bebas 
secara bersama-sama berpengaruh terhadap variabel terikat. Berdasarkan hasi uji $\mathrm{F}$ (uji model / uji simultan), diperoleh Nilai F hitung $=23.051$ seperti pad tabel berikut:

Tabel 1, Uji F ANOVA

\begin{tabular}{|l|l|l|l|l|l|}
\hline & $\begin{array}{l}\text { Sum of } \\
\text { Squares }\end{array}$ & df & mean & F & Sig. \\
\hline 1 Regression & 169.457 & 2 & 84.728 & 23.051 & $.000^{81}$ \\
Residual & 124.976 & 34 & 3.676 & & \\
\hline Total & 294.432 & 36 & & & \\
\hline
\end{tabular}

Bila Nilai $F$ hitung dibandingkan dengan $F$ tabel (4.130) dengan $n=3$ ' maka $F$ hitung lebih besar $F$ tabel (23.051 lebih besar 4.130) dengan probabilitas 0,00 lebih kecil 0,05, artinya: kemampuan bawahan dan gaya kepemimpinan secara simultan berpengaruh signifikan terhadap variabel terikat yaitu: efektivitas organisasi, sehingga hipotesis pertama diterima.

Uji Hipotesis 2 (Uji t), Hipotesis kedua menyatakan diduga variabel bebas gaya kepemimpinai (X2 ) secara berpengaruh dominan terhadap variabel terikat efektivitas organisasi (Y). Dari hasil analisis regresi diperoleh persamaan regresi sebagai berikut: $\mathrm{Y}$ $=-0.187+0.288 \mathrm{X} 1+0.427 \mathrm{X} 2$. Konstanta negatif $(-0.187)$ menunjukan bahwa: apabila tidak digunakan variabel kompetensi bawahan (XI) dan gaya kepemimpinan (X2) maka terjadi penurunan efektivitas organisasi; Koefisien regresi kemampuan bawahan 0.288 menunjukkan bahwa: kompetensi bawahan memiliki pengaruh positif atau searah terhadap efektivitas organisasi, artinya jika kompetensi bawahan meningkat, maka akan menyebabkan peningkatan efektivitas organisasi. Secara statistik kompetensi bawahan berpengaruh signifikan terhadap efektivitas organisasi, hal ini ditunjukkan dari thitung (2.448) lebih besar t tabei (2.032) dengan probabilitas $0,020<$ 0,05 .

Koefisien regresi gaya kepemimpinan sebesar 0,427 menunjukkan bahwa gaya kepemimpinan memiliki pengaruh positif atau searah terhadap efektivitas organisasi, artinya semakin baik gaya kepemimpinan akan menyebabkan peningkatan efektivitas organisasi. Secara statistik gaya kepemimpinan berpengaruh signifikan terhadap efektivitas organisasi, ditunjukkan dari t hitung (3.970) $>\mathrm{t}$ iabei (2.032) dengan probabilitas $0,000<0,05$.

Berdasarkan hasil Uji t yang telah dijelaskan di atas diperoleh hasil kompetensi bawahan dan gaya kepemimpinan berpengaruh signifikan terhadap efektivitas organisasi. Selanjutnya untuk pengujian hipotesis kedua yang menyatakan diduga gaya kepemimpinan berpengaruh dominan terhadap efektivitas organisasi, dilakukan dengan cara melihat koefisien regr yang paling besar dan signifikan di antara variabel bebas. Berdasarkan persamaan regresi yang diperoleh, koefisien regresi kemampuan bawahan $=0.288$ dan koefisien regresi gaya kepemimpinan $=0,4$ Variabel gaya kepemimpinan memilliki nilai koefisien regresi paling besar dan signifikan XI (0.288) lebih kecil X2 (0.427), sehingga berdasarkan hasil tersebut maka hipotesis kedua yang menyatakan bahwa gaya kepemimpinan berpengaruh dominan terhadap efektivitas organisasi, diterima.

Besamya kontribusi/kemampuan variabel kompetensi bawahan (gaya kepemimpinan dalam menjelaskan efektivitas organisasi ditunjukkan nilai koefisien determinasi yang disesuaikan (adjusted $R^{2}$ ) yaitu sebesar 0,551 artinya variabel kompetensi bawahan dan variabel gaya kepemimpinan memberikan kontribusi sebesar $55,1 \%$ terhadap efektivitas organisasi sisanya sebesar $44.9 \%$ dijelaskan oleh variabel lain yang tidak dipergunakan dalam model regresi pada penelitian ini. 


\section{PEMBAHASAN}

Dari hasil analisis data telah membuktikan bahwa: kompetensi bawahan dan gaya kepemimpinan mempunyai pengaruh yang sigpifikan terhadap efektivitas organisasi. Hal im mendukung teori organisasi yang menempatkan unsur perilaku (bawahan dan pemimpin) sebagai laktor strategis dalam upaya pencapaian tujuan organisasi secara efektif.

Suatu organisasi adalah suatu integrasi dari sejumlah spesialis-spesialis yang bekerja sania sangat rasicnal dan impersonal untuk mencapai beberapa tujuan spesifik yang telah ditetapkan sebelumnya (Victor A Thomson dalam Thoha 1984: 125-126). Hal ini berarti: suatu organisasi pada hakekatnya adalah alat saling hubungan/interaksi satuan kerja yang memberikan mereka kepada orang yang ditempatkan dalam stniktur wewenang, sehingga pekerjaan dapat dikoordinasikan oleh perintah para pimpinan / atasan kepada para bawahan. Interaksi tersebut biasanya dicerminkan dalam bentuk kerja sama dalam rangka pencapaian tujuan organisasi secara optimal. Kerja sama antar pimpinan dan bawahan mutlak diperlukan scrta tindakan selayaknya bisa dipraktekkan bukan hanya konsep. Karena ada kecenderungan pada organisasi publik kerumitan sistem kerja dapat mengakibatkan sisteni komando yang tidak tegas, tidak jelas dan tidak sinkron. Dalam konteks kerja sama yang dikaitkan dengan hasil penelitian maka kerja sama antar pimpinan dan bawahan dilingkungan organisasi dikatakan cukup baik.

Pada variabel kompetensi bawahan, hasil penelitian mencatat bahwa Kompetensi bawahan, masih sangat terbatas, Sehingga dalam rangka meningkatkan efektivitas orgamsasi, yang perlu diperhatikan adalah: macam/jenis pelaiihan, kesesuaian pelatihan dengan pekerjaan, posisi kerja sebelumnya dan kemampuan menyelesaikan pekerjaan.

Terbatasnya kompetensi bawahan, terutama disebabkan karena terbatasnya pegawai yang sudah diikutkan dalam pelatihan dibidang kepegawaian. Seharusnya keahlian dan keterampilan dibidang kepegawaian merupakan kualifikasi pokok yang benar-benar dibutuhkan oleh aparat pemerintah daerah yang menangani urusan kepegawaian.

Sebagian besar personal yang diikutkan dalam program pelatihan adalah para pejabat struktural. Disisi lain yang mengetahui teknis pengerjaan/opeiasional suatu tugas adalah para bawahan/staf. Seharusnya ada kesesuaian antara pelatihan dan pekerjaan sehingga diklat teknis mestinya diikuti oleh para bawahan atau peluang yang sama diberikan juga kepada semua pengelola kepegawaian, bukan hanya pejabat struktural.

Personalia justru diarahkan untuk mengikuti diklat teknis lainnya yang nonkepegawaian (bendaharawan dan umum), yang bersifat melancarkan tugas-tugas rutin. Frekuensi pelatihan teknis kepegawaian juga perlu diprioritaskan dan merupakan kebutuhan pegawai.. Pengikutsertaan pegawai pada berbagai pelatihanpun seharusnya sistematik dan selektif. Apalagi dengaii diundanglcannya Undang-Undang Otonomi Daerah maka, peningkatan kompetensi bawahan/pegawai didaerah sudah seharusnya diperhatikan. Hal ini harus dimulai dari aspirasi, konsep atau gagasan yang terdesentralisasi daerah tanpa menunggu instruksi dari pusat, sehingga pegawai yang dipekerjakan adalah mereka yang berkompeten sesuai bidang pekerjaan.

Dukungan kesehatan jiwa dan kebugaran fisikpun diperlukan dalam operasional kegiatan kepegawaian, karena kebugaran fisik membuat pegawai mampu dan tahan bekerja. Demikian juga gangguan kejiwaan akibat masalah sosial ekonomi, membuat pegawai yang bersangkutan tidak konsisten dan tidak berkonsentrasi melakukan 
pekerjaan. Berkaitan dengan pengalaman kerja, semakin sering seorang pegawai melakukan pekerjaan yang sama, semakin terampil dan semakin cepat penyelesaian pekerjaan, juga semakin banyak macam pekerjaan, pengalaman kerja pegawai tersebut semakin kaya dan luas sehingga. dalam penyelesaian pekerjaan memungkinkan peningkatan efektivitas.

Kompetensi merupakan faktor mendasar yang harus dimiliki dan ditingkatkan dalam upaya pencapaian efektivitas tujuan organisasi, untuk lebih mewujudkan fungsi pelayanan kepada masyarakat PNS yang emban oleh organisasi. Selain seorang pemimpin yang handal dan mampu menerapkan gaya kepemimpinan secara tepat, tidak kalah penting adalah tersedianya bawahan/pegawai yang memiliki berbagai keunggulan (berkompeten), karena pada dasamya pegawai juga memiliki andil yang sama besar terhadap keberhasilan organisasi guna mengoptimalkan pelayanannya kepada masyarakat PNS.

Pada variabel gaya kepemimpinan, hasil analisis juga membuktikan bahwa tingkat kepemimpinan, mencapai tingkat baik dan dominan. Yang perlu ditingkatkan untuk lebih mengefektifkan organisasi adalah: pengaturan aktivitas kerja bawahan, pemberian informasi tentang syarat pekerjaan dan penetapan standar perilaku kerja. Sedangkan yang perlu dipertahankan dan dikembangkan adalah: gaya kepemimpmanan yang bersedia menerima ide/pendapat bawahan, membanlu bawahan memecahkan masalah, mengutamakan tercapainya tujuan, ketegasan pelaksanaan disiplin, serta penggunaan prosedur-prosedur kerja yang umum.

Bila pimpinan bersedia menerima ide/pendapat bawahan maka bawahan merasa terlibat dalam setiap kebijakan/keputusan yang diambil oleh pimpinan sehingga, bawahan tidak hanya mengeijakan tetapi ikut bertanggung jawab dalam pelaksanaan kebijakan tersebut. Pimpinan tidak hanya sebagai pendengar atau penonton saja, bila bawahan menemui kendala dalam penyelesaian pekerjaan, tetapi ikut peduli dengan masalah bawahan dan memberikan solusi kepada bawahan.

Dilingkungan PNS dalam rangka menjamin tata tertib dan kelancaran pelaksanaan disiplin pelaksanaan tugas pekerjaan, telah dibuat siiatu ketentuan Peraturan Disiplin PNS (Peraturan Pemerintah Nomor 30 Tahun 1980) dan ketentuan pelaksanaannya ditetapkan dengan Surat Edaran Kepala Badan Administrasi Kepegawaian Negara Nomor 23/SE/1980 Tahun 1980, sebagai suatu peraturan yang memuat keharusan, larangan dan sanksi apabila keharusan tidak dilaksanakan atau larangan dilanggar.

Salah satu tolak ukur dari kedisiplinan ini adalah kehadiran dan kepulangan pegawai tepat waktu sesuai jadwal yang ditentukan. Bentuk disiplin lain adalah ketepatan ddam melaksanakan tugas kerja atau lebih menekankan pada output. Pegawai dituntut untuk dapat menyelesaikan tugasnya sesuai jadwal yang ditentukan. Hasil analisis data memberikan infromasi bahwa rata-rata pegawai memiliki kondite yang baik sehubungan dengan penegakan disiplin pada organisasi.

Sesuai tanggapan responden, bahwa secara rata-rata efektivitas organisasi tergolong cukup baik (rata - rata mean 3.89), sehingga perlu diperhatikan beberapa item untuk peningkatan efektivitas organisasi kearah yang lebih baik.

Efektivitas organisasi yang dimaksud berkenaan dengan indikator pendekatan sistem dalam organisasi. Analisis rata - rata mean dari variabcl efektivitas organisasi, menunjukan bahwa item pendekatan sistem dalam organisasi, yang perlu ditingkatkan adalah pada indikator: pemilihan dan penempatan pegawai sesuai latar belakang kemampuannya pada disain pekerjaan yang tepat, penyusunan dan pencapaian target program jangka pendek, serta penyusunan dan pencapaian target program jangka 
panjang.

Pada indikator pemilihan dan penempatan pegawai. Kecenderungan penempatan PNS yang berlaku selama ini tidak berdasarkan disiplin ilmu / latar belakang kemampuan serta pelatihan yang telah diikuti. Dari segi kompetensi yang dimiliki, seorang pegawai dapat saja mengerjakan tugasnya namun pengawai tersebut membutulikan waktu penycsuaian diri yang cukup lama bila dibandingkan dengan pegawai yang memilild latar belakang kemampuan yang sepadan dengan bidang yang ditempati. Sehingga bukan saja tercapainya tujuan penyelesaian suatu pekerjaan tetapi dapat diberikan kesempatan kepada pegawai untuk pengembangan kreatifitasnya, dengan demikian dapat menjadi motivasi bagi pegawai untuk meningkatkan efektivitas pelayanannya kepada masyarakat PNS lainnya yang dikenal dengan semboyan 3T (tepat waktu, tepat sasaran dan tepat aturan).

Obyek tempat penelitian ini telah menetapkan program jangka pendek dan program jangka panjang yang termuat dalam Renstra unit. Namun pencapaian program belum maksimal karena, terdapat berbagai kendala antara lain: fasilitas yang belum memadai, ketersediaan SDM yang kuiang sepadan dengan bidang tugas, serta adanya frekuensi pemindahan pegawai yang tidak menentu. Misalnya: seorang pegawai yang telah dibekali dengan pelatihan dan pengalaman pada bidang kepegawaian, karena pertimbangan promosi jabatan ataupun kebutuhan unit lain, hams mengalami pemindahan unit kerja. Hal ini akan nienimbulkan kepincangan untuk dapat merealisasikan program yang telah ditetapkan, karena untuk mendapatkan seorang pegawai yang memilild keahlian yang sama atau sepadan dibidang kepegawaian, tentunya membutuhkan waktu untuk penyesuaian.

Sedangkan indikator yang perlu dipertahankan dan dikembangkan adalali: adanya kerjasama antar individu dalam kelompok kerja untuk merealisasikan tujuan organisasi, adanya kesediaan dan keterbukaan pemimpin untuk menelaah persoalan yang muncul, serta adanya penetapan karakteristik dan spesifikasi tujuan strategis dan sasaran yang akan dicapai, adanya kerjasama antar individu dalam kelompok kerja untuk merealisasikan tujuan organisasi,

Suatu organisasi tidak mungkin mencapai efektivitas yang baik tanpa didukung oleh efektivitas para anggotanya. Sebab itu kerja sama dalam bentuk "team work" selayaknya dipertahankan dan dikembangkan. Kerja sama ini dapat diciptakan melalui arahan kerja, koordinasi, proses komunikasi yang baik dengan dukungan ikiim kerja yang kondusif.

Keputusan untuk meningkatkan efektivitas organisasi berkenaan dengan variabel kompetensi bawahan dan gaya kepemimpinan, dalam hal ini jika kompetensi bawahan dan gaya kepemimpinan ditingkatkan maka diharapkan efektivitas organisasi akan meningkat.

\section{KESIMPULAN DAN SARAN KESIMPULAN}

Secara umum responden mengakui pentingnya efektivitas dilingkungan pemerintah daerah dan efektivitas organisasi dapat dikatakan baik. Kompetensi bawahan yang dimiliki oleh pegawai, diketahui rata-rata pegawai niemiliki kompetensi yang cukup baik sehingga perlu dilakukan upaya peningkatan kompetensi sesuai tupoksi yang diemban. Rata-rata responden mengakui pentignya penerapan gaya kepemimpinan yang relevan dengan organisasi pemerintah daerah dan dapat dikatakan gaya kepemimpinan yang berlaku adalah baik.

Kompetensi bawahan dan gaya kepemimpinan secara bsrsama-sama mempimyai 
pengaruh yang signifikan terhadap efektivitas organisasi. Kedua variabel bebas yaitu kompetensi bawahan dan gaya kepemimpinan mampu mempengaruhi efektivitas organisasi sebesar $55,1 \%$, sisanya sebesar $44.9 \%$ dijelaskan oleh variabel lain yang tidak diteliti. Gaya kepemimpinan merupakan variabel yang paling dominan dalam mempengaruhi efelrtivitas organisasi.

\section{SARAN}

Jika mgin meningkatkan efektivitas organisasi, maka pimpinan disarankan dapat mengoptimalkan perannya dalam organisasi melalui pendekatan perilaku karena sesuai hasil penelitian melalui pendekatan perilaku, gaya kepemimpinan terbukti berpengaruh positif dan dominan untuk mengefektifkan organisasi.

Kajian tentang efektivitas organisasi, disarankan Menggunakan variabel bebas lainnya dalam penelitian, karena sumbangan variabel bebas tersebut, diyakini dapat berpengaruh terhadap efektivitas organisasi. Menggunakan variabel penelitian yang sama, tetapi menggunakan analisis yang bsrbeda atau pula melakukan penelitian replikasi dengan menambah jumlah variabel yang sudah ada sehingga hasil analisis yang diperoleh akan menjadi lebih baik.

\section{DAFTAR RUJUKAN}

Gibson, Ivancevich, Donnely, 1996, Perilaku, Struktur dan Proses, Edisi Kedelapan, Binarupa Aksara, Jakarta.

Mangkunegara, Prabu Anwar, 2005, Manajemen Sumber Daya Manusia Perusahaan, PT. Remaja Rosdakarya, Bandung. ^ 2006, Evaluasi Kinerja SDM, PT.Remaja Rosdakarya, Bandung.

Nawawi, Hadari, 2003, Kepemimpinan Mengefektifkan Organisasi. Cetakan Pertama. UGM University Press, Yogyakarta

Sedarmayanti, 2003, Good Governance (Kepemerintahan Yang Baik), Mandar Maju, Bandung.

Siagian, Sondang P, 1979, Peranan Stafdalam Manajemen, Gunung Agung, Jakarta. — 2003, Teori dan Praktek kepemimpinan, Cetakan Ke-5, Rineka Cipta, Jakarta.

Simanjuntak, 2005, Manajemen dan Evaluasi Kinerja, Fakultas Ekonomi Universitas Indonesia, Jakarta.

Suprihanto, J., Harsiwi, M dan Prakosa, H, 2003, Perilaku Organisasional, Edisi Pertama, STIE YKPN, Yogyakarta.

Robbins, 1994, Teori Organisasi (Struktur, Desain\& Aplikasi), Arcan, Jakarta.

Thoha, M., 1984, Dimensi - Dimensi Prima Administrasi Negara, Cetakan kedua. Rajawali, Jakarta.

Undang - undang Nomor 22 Tahun 1999 tentang Pemerintahan Daerah.

Undang - undang Nomor 25 Tahun 1999 tentang Perimbangan Keuangan antara Pemerintah Pusat dan Pemerintah Daerah; 